\title{
Przywództwo akademickie w sytuacji zmiany i niepewności
}

\author{
Beata Mazurek-Kucharska \\ Katedra Zarzadzania Zasobami Ludzkimi, Instytut Ekonomiczny, \\ Wydział Nauk o Zarządzaniu i Bezpieczeństwie, Społeczna Akademia Nauk w Warszawie
}

Przywódcy wyobrażają sobie porywająca przyszłość i staraja się nadać jej kształt, zamiast siedzieć, obserwując, jak przyszłość rozgrywa się wokół nich

Chris Lowney

\begin{abstract}
W artykule został przedstawiony empiryczny model przywództwa akademickiego w Polsce, oparty na wymiarach relacji międzyludzkich. Prezentowane wyniki badania własnego z 2017 r. stanowią kontynuację wcześniejszych badań autorki z lat 2010-2015. Wyodrębniono podstawowe wymiary relacji interpersonalnych, które w opinii badanych podnoszą jakość kapitału ludzkiego w środowisku akademickim, a także bariery w relacjach, do których należy m.in. brak tradycyjnego wzorca przywództwa wśród przełożonych i władz akademickich. W obecnych badaniach (IDI) uzyskano siedem empirycznych wymiarów przywództwa akademickiego; są to: posiadanie dojrzałej wizji rozwoju uczelni, postawa współpracy i szacunku, otwartość na zamianę i internacjonalizację, szacunek do prawa i tradycji akademickiej, wysokie standardy moralne i kompetencyjne, otwartość na dialog, interdyscyplinarna wiedza biznesowa.
\end{abstract}

Słowa kluczowe: przywództwo, zmienność, niepewność, model VUCA, relacje międzyludzkie, polskie szkolnictwo wyższe, metoda indywidualnego wywiadu pogłębionego

\section{Wprowadzenie}

Problematyka przywództwa inspiruje i intryguje badaczy wielu różnych dyscyplin naukowych. Dzieje się tak dlatego, że w historii świata wiele przełomowych wydarzeń, odkryć, rewolucji, losów narodów i państw, rodzących się ruchów politycznych i społecznych, wzlotów i upadków firm, powstawanie i upadki fortun 
nastąpiły w wyniku działania animatorów i liderów tych zmian - przywódców, których nazwiska utrwaliły się w księgach, wspomnieniach, przekazach i anegdotach, często znanych wielu pokoleniom. Historia cywilizacji dowodzi, że w sile przywództwa tkwi wielka moc, która jest w stanie zmieniać historię, oddziaływać na losy pokoleń, budować i rozwijać lub niszczyć i unicestwiać, często w imię wyartykułowanych lub przemilczanych wartości i norm społecznych. Poszukiwanie wzorca przywództwa i idealnego modelu przywódcy od lat stanowi przedmiot dyskusji i wielokierunkowych badań, prowadzonych przez specjalistów takich dziedzin, jak psychologia, socjologia, antropologia kulturowa, nauki polityczne czy nauki o zarządzaniu. Wraz z rozwojem tych nauk oraz pojawianiem się nowych podejść teoretycznych i paradygmatów badawczych zmianie ulegał cel samych badań. Podejmowano bowiem badania nad poszukiwaniem odpowiedzi na pytania o uwarunkowania zdolności przywódczych, prowadząc, trwającą w XX w. przez wiele lat, dyskusję nad rolą czynników dziedzicznych, biologicznych, wrodzonych oraz nabytych i środowiskowych, sprzyjających ukształtowaniu się silnych wzorców przywódczych. Analizowano także zestawy cech i typów osobowości przywódców, ich uzdolnienia, kompetencje i umiejętności, aby opisać, a także kształtować, sylwetkę psychologiczną efektywnego przywódcy. Podejmowano analizy nad wzajemnymi uwarunkowaniami cech osobowościowych i sytuacji zadaniowej, które wzajemnie oddziałują na siebie, wspomagając lub osłabiając siłę autorytetu przywódcy w otoczeniu. Opracowano wiele modeli przywództwa, typowych dla różnych wariantów środowiska, sytuacji, miejsca i czasu, w których przywódca wywiera wpływ na otaczających go ludzi, prowokując pożądane działania i ukierunkowując na osiągnięcie zakładanego celu (zob. np. Lewin, Lippit, White, 1939; Fiedler, 1967; Stogdill, 1974; Blanchard, Zigarmi, Zigarmi, 1985; Tichy, Devanna, 1986; Fiedler, Garcia, 1987; Morrison, 2000; Giuliani, 2003; Northouse, 2007; Gobillot, 2008; Avery, 2009; Bass, 2010; Palmer, 2010; Ulrich, 2015).

Szczególne zainteresowanie problematyką przywództwa budzą rozważania na temat roli i znaczenia przywódcy w sytuacji zmian, niepewności i kryzysu, w jakiej znajduje się organizacja (Wojciechowska-Filipek, Mazurek-Kucharska, 2014). Dzieje się tak prawdopodobnie dlatego, że w sytuacji niepewności, nieoznaczoności i nowości spada poczucie bezpieczeństwa osób zaangażowanych w zmianę, wzrasta zaś potrzeba powierzenia swoich losów opiece osoby budzącej powszechny szacunek, zaufanie i nadzieję na sprawne i rozsądne przeprowadzenie grupy przez nieznany i zagrażający obszar nieoznaczoności (Kozielecki, 1977; Gigol, 2015; Mazurek-Kucharska, 2015; Flis, Mazurek-Kucharska, 2016). Wzrasta wówczas poziom koncentracji decydentów na procesie efektywnego zarządzania wszystkimi zasobami organizacji, także zasobami ludzkimi. To właśnie zaangażowanie pracowników, wysoki poziom partycypacji i powszechna lojalność mogą być 
decydującymi czynnikami w tym momencie rozwoju (lub załamania się kondycji) organizacji. Zaufanie do przywódcy, jego roztropność, odwaga, dojrzałość i wysoki poziom kompetencji społecznych, a także odporność na stres, zrównoważenie i entuzjazm mogą stanowić silne argumenty w procesie zarządzania zespołem pracowników w sytuacji podwyższonego ryzyka i percypowanego zagrożenia (Witkowski, Listwan, 2008; Juchnowicz, 2009; Baron, Armstrong, 2012; Cascio, Boudreau, 2016).

Do opisu tego typu dynamicznych, ryzykownych i nieoznaczonych sytuacji wykorzystuje się niekiedy model VUCA, dobrze oddający charakterystykę sytuacji, a także subiektywny nastrój naprężenia i kontekstu działania przywódcy w tego typu warunkach.

Model VUCA został wprowadzony w celu scharakteryzowania skomplikowanej, dynamicznej, trudnej do poznania i prognozowania rzeczywistości, z jaką mamy do czynienia $w$ warunkach permanentnych zmian, przeobrażeń, globalizacji, szybkiego tempa wzrostu nowych technologii, transformacji i rozwoju (Bennett, Lemoine, 2014a, 2014b). Autorzy koncepcji w ekspresyjny sposób przedstawili tę sytuację i towarzyszące jej przeżycia uczestników w okrzyku: Hey, it’s crazy out there!. Przestrzeń VUCA odnosi się do opisu sytuacji, w której mamy mało informacji lub są one niejednoznaczne, mogą więc skłaniać do wielu interpretacji, a przez to trudno jest wybrać kierunek działania i przewidzieć skutki podjętej aktywności.

Termin VUCA to akronim pojęć: volatility, uncertainty, complexity, ambiguity. Volatility (zmienność) opisuje rzeczywistość, w której stawiane nam wyzwania (challenge) są nieoczekiwane lub niestabilne (unexpected or unstable), podobnie jak nieznany jest czas trwania takiego stanu rzeczy, chociaż wiedza o tym jest możliwa do zdobycia.

Uncertainty (niepewność) oznacza stan, w którym brakuje informacji dotyczących np. przyczyn lub przewidywanych konsekwencji zdarzenia.

Complexity (złożoność) odnosi się do sytuacji, w której istnieje wiele jej części składowych (parts) i zmiennych (variables), gdzie część informacji jest dostępna i przewidywalna, ale ich wielkość i charakter są przytłaczające i trudne do przetworzenia, zwłaszcza gdy należy tego dokonać szybko i trafnie.

Ambiguity (niejednoznaczność) dotyczy z kolei sytuacji, kiedy związki przyczynowe i wzajemne relacje są nieznane i niejednoznaczne, a interpretacje mogą być różne.

Jest oczywiste, że prowadząc rozważania nad efektywnym przywództwem w środowisku VUCA, zwraca się szczególną uwagę na determinanty efektywnych zachowań przywódczych, osobowość przywódcy, jego specyficzny potencjał kompetencyjny i atrybuty, które pozwalają wyróżnić go spośród grupy liderów 
i menedżerów, którzy, co prawda, zarządzają w sposób efektywny, ale nie są postrzegani i traktowani jako przywódcy (Mazurek-Kucharska, 2006a, 2006b, 2006c; Palmer, 2010).

Coraz większą wagę przywiązuje się do tych wymiarów funkcjonowania przywódcy w warunkach VUCA, które są powiązane z szeroko rozumianą odpornością, wytrzymałością, zdolnością do długotrwałej koncentracji i umiejętnością szybkiej regeneracji i powrotu do stanu równowagi psychicznej po przebytym stresie, niekiedy nawet traumie, towarzyszącej utracie bezpieczeństwa i dużemu obciążeniu emocjonalnemu. Podkreśla się, że szczególnie cenna jest duża elastyczność, giętkość i zwinność (agility), towarzyszące przebiegowi procesów poznawczych, a także umiejętność określana jako rezyliencja (Arora, Rangnekar, 2015; Mishra, McDonald, 2017). Rezyliencja jest rozumiana jako umiejętność lub proces szybkiej adaptacji do zmieniających się warunków otoczenia, uodpornianie się na silny lub długotrwały stres oraz towarzysząca tej umiejętności inna cecha, a mianowicie plastyczność umysłu. Rezyliencja to także umiejętność rozwoju w trudnych warunkach - poprzez wykorzystanie siły przeciwności i zakłóceń jako, paradoksalnie, źródła siły i motywacji nie tylko do przetrwania, lecz także do harmonijnego rozwoju (adversity and disruptions) (Richardson, 2002; Quinlan i in., 2015).

Osoba o wysokim poziomie rezyliencji charakteryzuje się zdolnością do odzyskiwania utraconych lub osłabionych sił i odpornością na działanie szkodliwych czynników, czerpiąc siłę rozwojową w trakcie pokonywania przeszkód i przeciwności (Werner,1989; Tugade, Fredrickson, Barrett, 2004).

Zainteresowanie tego typu badaniami i analizami może stanowić nowy kontekst badań nad uwarunkowaniami efektywnego przywództwa we wszechobecnych sytuacjach VUCA. Być może stanie się też inspiracją do pogłębienia analiz nie tylko $\mathrm{w}$ środowisku globalnych organizacji $\mathrm{i} w$ warunkach silnej konkurencyjności przedsiębiorstw, lecz także w kontekście rozwoju organizacji, które do niedawna były postrzegane jako stabilne, przewidywalne i oparte na tradycyjnych wartościach i zasadach funkcjonowania. Do tego typu organizacji można m.in. zaliczyć uczelnie w Polsce, które w ostatnim okresie przeżywają jednak oznaki szybko zbliżających się zmian i turbulencji. Napięcia i stres nie tylko wynikają z zapowiadanych zmian legislacyjnych, lecz także są związane ze zmieniającym się modelem funkcjonowania uczelni i nowymi wyzwaniami, jakie zostały postawione przed kadrą odpowiedzialną za dalszy rozwój i podnoszenie konkurencyjności poszczególnych jednostek akademickich oraz - ogólnie - nauki polskiej. Dlatego też podjęto wstępne badania i analizy nad zagadnieniem przywództwa w środowisku akademickim, nawiązujące do wcześniej prowadzonych badań empirycznych i analiz, odnoszących się do problematyki znaczenia relacji interpersonalnych w budowaniu wartości kapitału ludzkiego w środowisku 
akademickim (Mazurek-Kucharska, 2016). Celem prowadzonych badań było odtworzenie struktury wymiarów dotyczących jakości relacji międzyludzkich, jakie - zdaniem badanych - mają znaczenie w budowaniu wartości kapitału ludzkiego w środowisku akademickim. Jeden z celów szczegółowych badania dotyczył analizy wymiarów przywództwa akademickiego, czyli analizie danych empirycznych pod kątem uzyskania odpowiedzi na następujące pytanie badawcze: „Jakie wymiary przywództwa są identyfikowane przez badanych jako ważne dla modelu przywództwa w środowisku akademickim?”. Temu właśnie fragmentowi analiz są poświęcone dalsze części niniejszego artykułu.

\section{Rola przywódcy w środowisku akademickim w opinii pracowników naukowych}

Badanie własne nad rolą relacji interpersonalnych $\mathrm{w}$ podnoszeniu jakości i wartości kapitału ludzkiego w polskich uczelniach, stanowiące efekt kilku lat własnych działań badawczych i praktyki konsultingowej (2010-2015), pozwoliło ustalić sześć podstawowych wymiarów relacji interpersonalnych, które w opiniach badanych podnoszą jakość kapitału ludzkiego w środowisku akademickim (Mazurek-Kucharska, 2016). Są nimi następujące wymiary relacji interpersonalnych:

1) gotowość do dzielenia się wiedzą,

2) postawa współpracy,

3) unikanie konfliktów,

4) postawa tolerancji,

5) wysoka kultura osobista,

6) otwartość na dialog i wymianę poglądów.

Badani pracownicy naukowo-dydaktyczni podkreślali, że są, na ogół, zadowoleni z atmosfery panującej w ich środowisku, a także to, że cenią sobie fakt, iż w ich środowisku panuje atmosfera tolerancji i otwartości na różnorodność poglądów i postaw życiowych. Sprawia im satysfakcję, że mogą uczestniczyć w zaciekłych niekiedy dyskusjach z osobami o innym niż one światopoglądzie, gdyż, jak twierdzą, różnorodność sprzyja ich rozwojowi i obiektywnemu poznawaniu świata. $\mathrm{Na}$ ogół są zdania, że środowisko, w którym pracują, koncentruje osoby o wysokim poziomie kultury osobistej. Podkreślali jednak, że spotykają się w swoim środowisku także z przykładami niskiej kultury dyskusji (co wskazano jako czynnik utrudniający dobre relacje interpersonalne), a niekiedy także, choć nie tak często, z przykładami niskiej kultury osobistej (co przejawia się przede wszystkim w braku dbałości o porządek i czystość miejsca pracy). Przyznawali ponadto, że 
w tym środowisku osoby unikają otwartych konfliktów i konfrontacji, co jednak, ich zdaniem, nie oznacza braku konfliktów. Konflikty na ogół są ukryte, a niechęć, frustracja i agresja są maskowane i zawoalowane. Przyznają, że negatywne emocje rodzą napięcia i problemy w relacjach pomiędzy pracownikami, a także między pracownikami a przełożonym. Tylko niektórzy przyznali, że są zdecydowani, aby otwarcie rozmawiać o problemach w miejscu pracy. Większość podkreślała natomiast, że problemy i konflikty, które występują na uczelni, są odwieczne, nie do rozwiązania i szkoda nawet zakładać, że można je rozwiązać lub im zapobiec. Badani przyznali, co szczególnie ważne, że na ogół w sytuacji występowania konfliktów lub problemów interpersonalnych są prawie zawsze zdani na siebie samych, ponieważ inne osoby, w tym także przełożeni, nie chcą się angażować w nieprzyjemne sytuacje, gdyż mogą w wyniku włączenia się w konflikt zbyt wiele stracić lub narazić się na nieprzyjemności i spadek popularności w środowisku.

Można więc stwierdzić, że wymiar relacji intelektualnych i zadaniowych $\mathrm{w}$ relacjach interpersonalnych $\mathrm{w}$ tym środowisku jest na ogół postrzegany jako źródło zadowolenia i satysfakcji. Natomiast emocjonalna strona relacji, zwłaszcza w sytuacji występowania problemów lub konfliktów, wydaje się być źródłem maskowanych niepokojów, frustracji i nieskutecznych strategii radzenia sobie z problemami, wynikających także $\mathrm{z}$ dostrzeganych słabości $\mathrm{w}$ relacjach z przełożonym.

Dalsze analizy wyników badania pozwoliły na wskazanie dziewięciu czynników, identyfikowanych jako podstawowe bariery w procesie budowania relacji interpersonalnych $\mathrm{w}$ środowisku akademickim. Badani wskazali następujące bariery:

1) postawa rywalizacji w zespole pracowniczym,

2) obecność skrytych strategii i manipulacji w relacjach,

3) niski poziom współpracy między młodszym a starszym pokoleniem,

4) zazdrość i zawiść,

5) istniejące koneksje i układy towarzyskie,

6) nepotyzm,

7) niski poziom kultury dyskusji akademickiej lub jej całkowity brak,

8) odhumanizowanie procesu relacji interpersonalnych na rzecz biurokratyzacji pracy,

9) brak tradycyjnego wzorca przywództwa wśród przełożonych i władz akademickich.

Wyartykułowanie ostatniego z czynników, czyli braku wzorca przywództwa w środowisku akademickim, stało się inspiracją do podjęcia kolejnego etapu badania, ukierunkowanego na identyfikację tych wymiarów przywództwa, które badani identyfikują i wskazują jako ważne w przywództwie akademickim. Taki 
przedmiot badania wydał się interesujący także z innego punktu widzenia, a mianowicie w światowej literaturze przedmiotu dostrzega się potrzebę systematycznych badań i analiz nad zagadnieniem przywództwa akademickiego (Fayolle, Redford, 2014), choć analizy tego typu badań nie są rozpowszechnione, na co zwracają uwagę m.in. także G.A. Stephen i J. Antony (2017). Jednocześnie waga tego zagadnienia jest podkreślana w wypowiedziach i dyskusjach poświęconych problematyce kluczowych zmian w szkolnictwie wyższym w Polsce i związanym $\mathrm{z}$ tym potrzebom kształtowania nowych wymiarów przywództwa w środowisku akademickim $^{1}$.

Ten etap badania, traktowany jako badanie pilotażowe, przeprowadzono w październiku i listopadzie 2017 r. wśród 33 osób, które wzięły udział we wcześniejszym etapie badania, ukierunkowanego na badanie jakości relacji interpersonalnych w środowisku akademickim.

Podobnie jak we wcześniejszym badaniu, metodą zbierania danych była metoda indywidualnych wywiadów strukturalizowanych (Individual-in-Depth Interview, IDI) oraz metoda dyskusji grupowych i tzw. burzy mózgów. Badanie jakościowe zostało zaplanowane jako badanie eksploracyjne. Dane, otrzymane w wyniku analizy wyników badania jakościowego, posłużyły do zaplanowania kolejnego etapu badania - ilościowego badania eksploracyjnego, realizowanego z wykorzystaniem autorskiego kwestionariusza ankiety QLUM².

W wyniku przeprowadzonych analiz wyników badania jakościowego możliwe było wygenerowanie wstępnego zestawu wymiarów przywództwa akademickiego, które to wymiary badani wskazują jako ważne w procesie kształtowania się nowej wizji i nowych zadań, jakie stoją przed kadrą zarządzającą polskimi uczelniami zarówno publicznymi, jak i prywatnymi (rysunek 1).

Jak wynika ze wstępnie wyprowadzonego modelu najważniejszych czynników określających wzorzec przywództwa akademickiego, badani pracownicy naukowo-dydaktyczni zwracają szczególną uwagę na wymiary wiążące kompetencje $\mathrm{z}$ wartościami i normami moralnymi (wymiary: wysokie standardy moralne i kompetencyjne stawiane przywódcy; szacunek do prawa i tradycji akademickiej; postawa współpracy i szacunku wobec wszystkich członków środowiska akademickiego) oraz na wymiary na podstawie interakcji interdyscyplinarnej wiedzy (w tym także biznesowej) i doświadczenia (wymiary: wielokierunkowa i interdyscyplinarna wiedza biznesowa; posiadanie dojrzałej wizji rozwoju uczelni),

1 Temu zagadnieniu zostały poświecone np. dyskusje panelowe w trakcie III Konferencji pt. Liderzy Zarządzania Uczelniq - LUMEN 2017, która odbyła się w Warszawie w dniach 14-15 listopada 2017 r. z inicjatywy firmy Public Consulting Group (PCG) i PCG Akademia.

2 Badanie pilotażowe, którego celem jest ustalenie poziomu rzetelności narzędzia QLUM, zostało podjęte przez autorkę w kwietniu $2018 \mathrm{r}$. 
a także na wymiary związane z postawami wobec zmiany, relacji międzyludzkich i gotowości do współpracy (wymiary: postawa współpracy; otwartość na dialog i wymianę poglądów z całym środowiskiem akademickim; otwartość na zmianę i szerokie kontakty międzynarodowe). Wymienione wymiary zdają się odgrywać ważniejszą rolę od zestawu generowanych w trakcie rozmów z badanymi na temat cech przywódcy i zestawu szczegółowych kompetencji ${ }^{3}$. Badani oczekują, że ważnym wymiarem przywództwa akademickiego będzie dojrzała wizja rozwoju uczelni, a także otwartość na procesy internacjonalizacji, powiązanej z gotowością do współpracy i szacunku wobec wszystkich członków środowiska.

\section{Rysunek 1. Wymiary przywództwa akademickiego w opiniach środowiska} pracowników naukowo-dydaktycznych

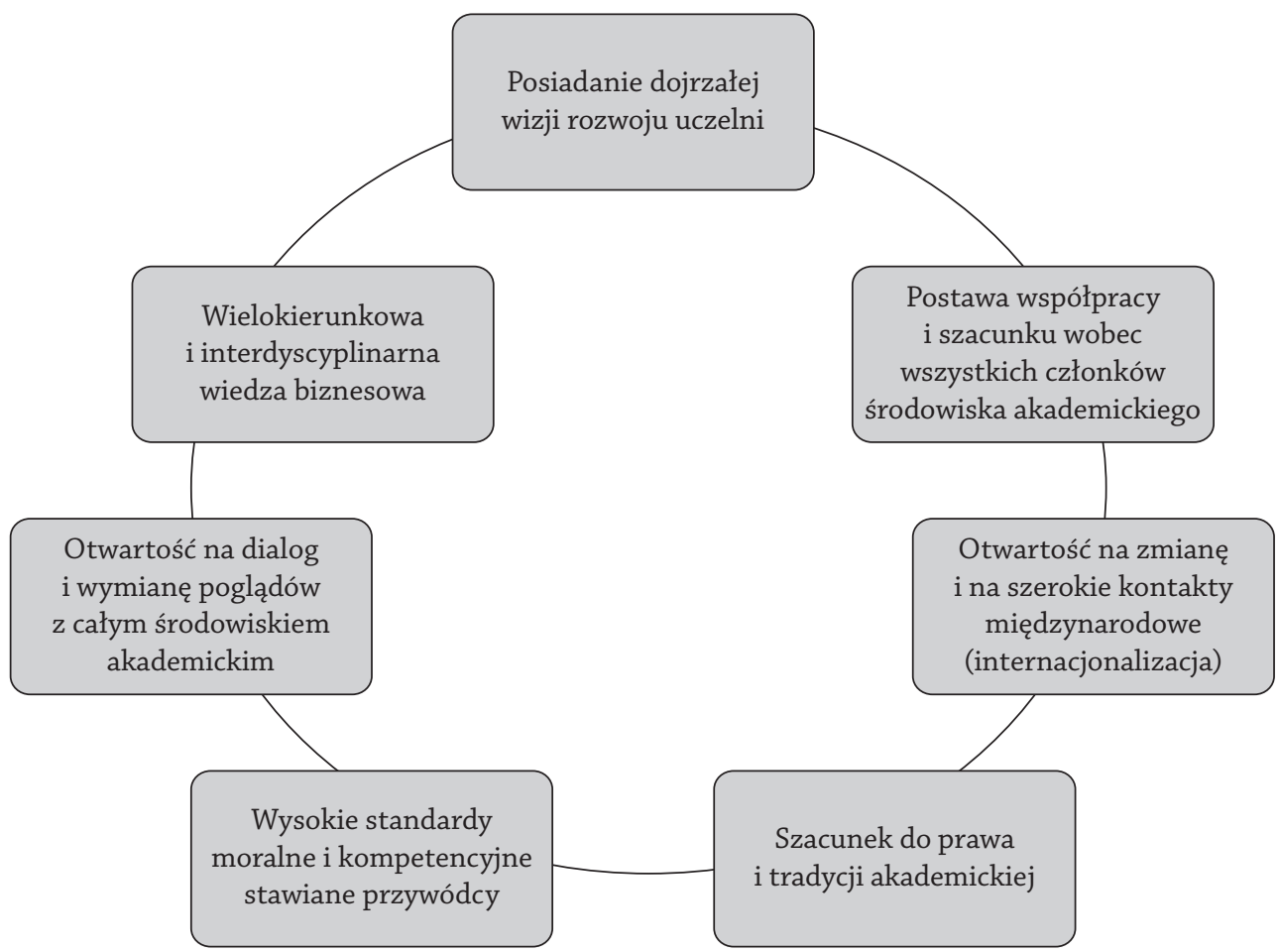

Źródło: opracowanie własne.

3 Ten fragment badania i analiz został pominięty w niniejszym, ograniczonym objętościowo, artykule. 


\section{Podsumowanie}

W niniejszym artykule podjęto próbę zasygnalizowania problematyki przywództwa, a zwłaszcza przywództwa akademickiego, jako interesującego zagadnienia, które powinno zostać podjęte i kontynuowane w ramach planowanych dalszych badań jakościowych i ilościowych.

Przedstawione wstępne, schematyczne wnioski z dotychczas przeprowadzonych analiz pozwoliły na wygenerowanie wyjściowego, na razie uproszczonego, modelu przywództwa akademickiego, który może posłużyć do planowania dalszych badań eksplanacyjnych.

Empiryczny model należy traktować jako wyjściowy i otwarty, a wygenerowane wymiary jako przestrzenie zmiennych, które zostaną wzięte pod uwagę w procesie planowania dalszych badań, związanych z poszukiwaniem polskiego modelu przywództwa akademickiego.

\section{Bibliografia}

Arora, R., Rangnekar, S. (2016). Moderating mentoring relationships and career resilience: Role of conscientiousness personality disposition. Journal of Workplace Behavioral Health, 31(1), 19-36.

Arora, R., Rangnekar, S. (2015). Relationships between emotional stability, psychological mentoring support and career resilience. Europe's Journal of Psychology, 11(1), 16-33.

Avery, C.G. (2009). Przywództwo w organizacji. Warszawa: PWE.

Baron, A., Armstrong, M. (2012). Zarzq̨dzanie kapitałem ludzkim. Uzyskiwanie wartości dodanej dzięki ludziom. Warszawa: Oficyna Wydawnicza Wolters Kluwer.

Bass, B.M. (2010). Two Decades of Research and Development in Transformational Leadership. European Journal of Work and Organizational Psychology, 8(1), 9-32.

Bennett, N., Lemoine, G.J. (2014a). What a difference a word makes: Understanding threats to performance in a VUCA world. Business Horizons, 57(3), 311-317.

Bennett, N., Lemoine, G.J. (2014b). What VUCA really means for you. Harvard Business Review, 92(1/2), 27.

Blanchard, K.H., Zigarmi, P., Zigarmi, D. (1985). Leadership and the One Minute Manager: Increasing Effectiveness through Situational Leadership. New York: Morrow. Bynander, F., Hart, P. (2006). When Power Changes Hands: The Political Psychology of Leadership Succession in Democracies. Political Psychology, 27(5), 707-730.

Cascio, W.F., Boudreau, J.W. (2016). Investing in People. Financial Impact of Human Resource Initiatives. Upper Saddle River, NJ: Pearson Education. 
Fayolle, A., Redford, D.T. (2014). Handbook on the Entrepreneurial University. Glos: Edward Elgar Publishing Limited.

Fiedler, F.E. (1967). A Theory of Leadership Effectiveness. New York: McGraw-Hill

Fiedler, F.E., Garcia, J.E. (1987). Leadership. Cognitive resources and performance. New York: McGraw-Hill.

Flis, R., Mazurek-Kucharska, B. (2016). Przedsiębiorstwo innowacyjne - stroma droga na szczyt. Case study. W: B. Mazurek-Kucharska, M. Dębski (red.), Zarządzanie małym i średnim przedsiębiorstwem w Polsce. Innowacyjne strategie, narzędzia i wdrożenia. Przedsiębiorczość i Zarządzanie, XVII(7, II), 55-67.

Gigol, T. (2015). Kryzys przedsiębiorstwa a przywództwo. Warszawa: Difin.

Giuliani, R.W. (2003). Przywództwo, Kraków: Wydawnictwo M.

Gobillot, E. (2008). Przywództwo przez integrację. Warszawa: Oficyna Wydawnicza Wolters Kluwer.

Juchnowicz, M. (red.) (2009). Kulturowe uwarunkowania zarządzania kapitałem ludzkim. Kraków: Oficyna Wydawnicza Wolters Kluwer.

Kozielecki, J. (1977). Psychologiczna teoria decyzji. Warszawa: PWN.

Lewin, K., Lippit, R., White, R.K. (1939). Patterns of aggressive behavior in experimentally created social climates. Journal of Social Psychology, 10, 271-301.

Lowney, Ch. (2011). Heroiczne przywództwo. Tajemnice sukcesu firmy istniejacej ponad 450 lat. Kraków: Wydawnictwo WAM.

Mazurek-Kucharska, B. (2015). Czynniki stymulującei hamujące innowacyjność przedsiębiorstw w opiniach przedsiębiorców. W: E. Gołębiowska (red.), Zarządzanie nowe perspektywy. Heurystyczne podejście do innowacyjności. Przedsiębiorczość i Zarządzanie, XVI(11, I), 81-94.

Mazurek-Kucharska, B. (2006a). Kompetencje i osobowość efektywnego przywódcy. W: T. Rostkowski (red.), Rozwój kompetencji przywódczych w Polsce. Recenzowany raport z badań. Warszawa: Oficyna Wydawnicza Szkoły Głównej Handlowej w Warszawie, 25-44.

Mazurek-Kucharska, B. (2006b). Kompetencje menedżera - stereotyp polski i australijski. Badania międzykulturowe. Edukacja Ekonomistów i Menedżerów. Problemy. Innowacje. Projekty, 3, 161-183.

Mazurek-Kucharska, B. (2006c). Kompetencje społeczne menedżerów i osób bezrobotnych. Własne badania porównawcze z lat 1996-2004. W: S. Konarski (red.), Kompetencje społeczno-psychologiczne ekonomistów i menedżerów. Teoria, badania, edukacja. Warszawa: Oficyna Wydawnicza Szkoły Głównej Handlowej w Warszawie, 141-160.

Mazurek-Kucharska, B. (2016). Rola relacji interpersonalnych w budowaniu wartości kapitału ludzkiego w środowisku akademickim. W: Ł. Sułkowski, A. Noworól, B. Mazurek-Kucharska (red.), Humanistyczne aspekty zarządzania wiedzą i kompetencjami. Przedsiębiorczość i Zarządzanie, XVII(7, II), 91-107.

Mishra, P., McDonald, K. (2017). Career resilience: An integrated review of the empirical literature. Human Resource Development Review, 16(4), 207-234. 
Morrison, A.J. (2000). Developing a global leadership model. Human Resource Management, 39(2, 3), 117-131.

Northouse, G. (2007). Leadership Theory and Practice. Thousand Oaks, CA: Sage Publications Inc.

Palmer, R.E. (2010). Przywództwo doskonałe. Warszawa: Wolters Kluwer.

Quinlan, A.E., Berbés-Blázquez, M., Haider, L.J., Peterson, G.D. (2015). Measuring and assessing resilience broadening understanding through multiple disciplinary perspectives. Journal of Applied Ecology, 53, 1-11.

Richardson, G.E. (2002). The metatheory of resilience and resiliency. Journal of Clinical Psychology, 58, 307-321.

Stephen, G.A., Antony, J. (2017). Academic leadership - special or simple. International Journal of Productivity and Performance Management, 66(5), 630-637.

Stogdill, R.M. (1974). Handbook of Leadership: A Survey of Theory and Research. New York: Free Press.

Tichy, N.M., Devanna, M.A. (1986). The Transformational Leader: The Key to Global Competitiveness. New York: John Wiley \& Sons.

Tugade, M.M., Fredrickson, B.L., Barrett, L.F. (2004). Psychological resilience and positive emotional granularity: Examining the benefits of positive emotions on coping and health. Journal of Personality, 72, 1161-1190.

Ulrich, D.O. (2015). The Leadership Capital Index: Realizing the Market Value of Leadership. Oakland, CA: Berrett-Koehler Publishers.

Werner, E.E. (1989). Children of the Garden Island. Scientific American, 260(4), 106-111.

Witkowski, S.A., Listwan, T. (red.) (2008). Kompetencje a sukces zarządzania organizacją. Warszawa: Difin.

Wojciechowska-Filipek, S., Mazurek-Kucharska, B. (2014). Zarzq̨dzanie w kryzysie. Aspekty organizacyjne i psychologiczne. Warszawa: Wydawnictwo CeDeWu.

\section{Summary}

\section{Academic Leadership in a Situation of Volatility and Uncertainty}

The article presents an empirical model of academic leadership in Poland, based on the interpersonal relations' dimensions. The presented results of the author's own research of 2017 constitute the continuation of the author's earlier research done in the years 2010-2015. Two things have been identified: the basic dimensions of interpersonal relations which - as viewed by the surveyed - improve the quality of human resources in the academic environment, and the barriers to the relations, one of which is the lack of traditional leadership role model within 
the groups of superiors and academic authorities. In the present study, seven empirical dimensions of the academic leadership have been identified. These are: a mature vision of the university's growth, co-operative and respect-showing stance, openness to change and internationalisation, respect for the law and academic tradition, high moral and competence standards, openness to dialogue, interdisciplinary business knowledge.

Keywords: leadership, volatility, uncertainty, VUCA model, interpersonal relations, Polish higher education, in-depth interview method

\section{Dr Beata Mazurek-Kucharska}

Doktor nauk humanistycznych w zakresie psychologii; psycholog biznesu, ekspert projektów wspierających rozwój innowacyjności i zarządzania kapitałem ludzkim, potencjałem wiedzy i relacji, wykładowca i koordynator modułu Managerial Skills na studiach Master of Business Administration (University of Central Lancashire, Lubelska Szkoła Biznesu Sp. z o.o.), wykładowca na Podyplomowych Studiach Menedżerskich w Instytucie Kapitału Ludzkiego w Szkole Głównej Handlowej w Warszawie. Autorka kilkudziesięciu publikacji naukowych oraz kilkunastu raportów z badań naukowych. Kieruje Katedrą Zarządzania Zasobami Ludzkimi w Instytucie Ekonomicznym oraz pełni obowiązki Dziekana Wydziału Nauk Humanistycznych w Społecznej Akademii Nauk w Warszawie. 